\title{
Road safety education and drivers behavior
}

\section{La educación vial y el comportamiento de los conductores}

\author{
Luís Montoro González
}

Published online: 22 November 2011

(C) Etrasa 2011

La estrategia de la educación, aunque pueda parecer un planteamiento exclusivo de nuestra época, no es en absoluto una novedad en la dilatada historia de la humanidad dentro del ámbito del tráfico, del transporte y la seguridad vial.

Las campañas y estrategias educadoras de alguna manera ya nos las encontramos en distintas épocas de la historia. Por ejemplo, un escrito del antiguo Egipto de hace 3.500 años decía: "No bebas mucha cerveza porque si te caes en la calle nadie querrá recogerte, y tu cabeza acabará en el polvo si coges tu carro y tropiezas con alguna piedra".

La importancia de la educación aparece también en otros muchos momentos de la historia. Por ejemplo, en el Diario de Madrid de 31 de Octubre de 1796, se decía: "A los muchachos y a la gente joven hay que advertirles de sus tonterías en la calle por medio de sus padres y parientes, haciéndoles ver que si una vez yerran el cruzado y son atropellados, no sirve de nada haberlo acertado cuarenta, y más que multarlos, lo mejor sería educarlos, pues con ello ganaríamos mucho para la seguridad y las buenas costumbres".

No se puede enfrentar el modelo sancionador con el educativo como vías para modificar el

L. M. González $(\bowtie)$

Catedrático de Seguridad Vial, Universidad de Valencia,

Presidente de la Fundación Española para la

Seguridad Vial (FESVIAL),

Valencia, Spain

e-mail: luis.montoro@uv.es comportamiento de los conductores. Ambos son necesarios, pero las investigaciones dejan claro que la educación tiene efectos mucho más positivos, eficaces y duraderos que la sanción, entre los que de manera sintética se podrían resaltar los siguientes: mediante la educación el sujeto aprende los peligros de una conducta, la mejor vía para modificar su comportamiento; el sujeto acaba cumpliendo las normas por seguridad y no por miedo a la sanción; con la educación el sujeto cumple la norma aunque no prevea la posibilidad de la sanción; bien educado el sujeto, al conocer los peligros y riesgos de una conducta, se convierte en transmisor de la seguridad vial; con la educación el conductor conoce los riesgos de no cumplir la norma, que siempre son mayores que la simple sanción económica; y finalmente, las investigaciones dicen claramente que la educación tiene mucha más permanencia en el tiempo que la sanción. En este sentido se podría decir que la sanción "inhibe" el comportamiento-algo muy interesante-, pero no lo "modifica" con estabilidad en el tiempo, algo que sí hacen la educación y la formación.

En este contexto, es importante destacar también que muchos legisladores sin experiencia en el ámbito de la seguridad han sido los inductores de que el modelo formativo en seguridad vial esté básicamente centrado en el cumplimiento de la norma con la amenaza de la sanción y no en la educación para seguridad. El modelo lógicamente ha mostrado con el 
tiempo su debilidad, puesto que el conocimiento de la norma sin más no garantiza necesariamente su cumplimiento y la sanción, por mucho que aumente, no ataja todas las conductas de riesgo.

Además, hay otra seria debilidad en este modelo en la que casi nadie ha reparado: existen numerosas conductas de riesgo que no están explícitamente prohibidas por la norma, como conducir con cuarenta grados de temperatura en el interior del vehículo, o con un fuerte estado de estrés, o bajo los graves problemas económicos que la crisis provoca en muchos conductores. Pero no estar prohibido, no significa que no pueda suponer un grave peligro para la seguridad cuando se maneja un vehículo con motor.
Por eso, en el modelo educativo-formativo es preciso también progresar y superar de una vez el binomio "lo prohibido es lo peligroso" y por ello sancionable; "lo no prohibido no peligroso". Este modelo, usado hasta ahora en muchos países, ha fracasado y además ha creado una grave disonancia en los conductores respecto a la seguridad.

Esto se ve muy claro en las autoescuelas y en la calle, donde una pregunta típica sigue siendo: ¿pero eso está prohibido?, o en su caso, ¿pero me van a multar por eso? Cuando la pregunta debería ser: ¿eso contribuye o no a mi seguridad? Si lográramos ese modelo y esta concepción, que son los que en buena medida se utilizan en el ámbito de la salud, cambiarían muchas cosas en el campo de la seguridad vial. 